\title{
The genus Paracloeodes (Insecta : Ephemeroptera : Baetidae) and its presence in South America
}

\author{
C. R. Lugo-Ortiz 1 \\ W. P. McCafferty 1
}

Keywords : Ephemeroptera, Baetidae, Paracloeodes, new species, South America.

The genus Paracloeodes (Insecta : Ephemeroptera : Baetidae) is newly reported from South America. Because of the discovery of species with hindwings and other characteristics not previously associated with Paracloeodes, a redescription of the genus is provided. Cladistic data suggest a South American center of origin for this Panamerican genus. Paracloeodes binodulus, n. sp., is described from larvae from northern Brazil, and is distinguished by the lack of hindwingpads and presence of small mesonotal tubercles. Paracloeodes eurybranchus n. sp., is described from larvae and female adults from north-central Argentina and southeastern Brazil; it is distinguished as larvae by the relatively large size, hindwingpads, and medially broad gills. Paracloeodes ibicui, n. sp., is described from a mature larva collected from Paraguay, and is distinguished by hindwingpads and abdominal coloration. Paracloeodes leptobranchus, n. sp., is described from larvae from Paraguay and southeastern Brazil, and is distinguished by relatively large size, hindwingpads, and slender gills.

\section{Le genre Paracloeodes (Insecta : Ephemeroptera : Baetidae) et sa présence en Amérique du Sud}

Mots clés : Ephemeroptera, Baetidae, Paracloeodes, espèces nouvelles, Amérique du Sud.

Le genre Paracloeodes (Insecta : Ephemeroptera : Baetidae) est signalé pour la première fois en Amérique du Sud. En raison de la découverte d'espèces présentant des ailes postérieures ainsi que d'autres caractères non associés jusqu'ici avec la définition de Paracloeodes, une redescription de ce genre est proposée. Des données cladistiques suggèrent un centre d'origine SudAméricain pour ce genre Panaméricain. Paracloeodes binodulus, n. sp., est décrit à partir de larves provenant du Brésil septentrional, et se distingue par l'absence de fourreaux alaires postérieurs et la présence de petits tubercules mésonotaux. Paracloeodes eurybranchus $\mathrm{n}$. sp., est décrit à partie de larves et d'adultes femelles provenant du Centre-Nord de l'Argentine et du Sud-Est du Brésil; les larves se distinguent par leur taille relativement élevée, leurs fourreaux alaires postérieurs et leurs branchies élargies dans la région médiane. Paracloeodes ibicui, n. sp., est décrit à partir d'une larve mature récoltée au Paraguay, et se distingue par ses fourreaux alaires postérieurs et sa coloration abdominale. Paracloeodes leptobranchus n. sp., est décrit à partir de larves provenant du Paraguay et du Sud-Est du Brésil, et se distingue par sa taille relativement grande, ses fourreaux alaires, et ses branchies étroites.

\section{Introduction}

Paracloeodes Day (Insecta : Ephemeroptera : Baetidae) is a poorly known genus of small minnow mayflies endemic to the Western Hemisphere (McCafferty \& Waltz 1990). It has been poorly docu-

1. Department of Entomology, Purdue University, West Lafayette, IN 47907 USA. mented because of difficulties associated with collecting larvae and in rearing and identifying adults. Only $P$. minutus (Daggy) is known from North America. Although previously unknown from South America, the genus has been recorded from the Mesoamerican Neotropics : P. portoricensis Traver from Puerto Rico (Traver 1938), P. lilliputian Kluge from Cuba (Kluge 1991), P. spp from Panama (Flowers 1991), P. minutus from Costa Rica (McCafferty \& Lugo-Ortiz 1996).

McCafferty et al. (1992) indicated that Paracloeodes is warm-water sublimited and humid favored in the Nearctic. Based on this and its presen- 
ce in the Greater Antilles they hypothesized that the affinities of the genus were Neotropical. Such ecological and distributional patterns were considered atypical for baetids, with only one other baetid genus, Fallceon Waltz \& McCafferty, having a similar pattern (McCafferty et al. 1992, Lugo-Ortiz et al. 1994). Lack of more detailed systematic, ecological, and distributional data precluded a definitive biogeographic assessment of Paracloeodes.

Our discovery of Paracloeodes from South America not only extends its known geographic range, but also extends the known range of morphological variability within the genus. Herein the genus is redescribed, four new species from South America are described, and the biogeography of the genus is discussed. The materials that formed the basis of this study are housed in the Purdue Entomological Research Collection, West Lafayette, Indiana, USA.

\section{Paracloeodes Day}

\subsection{Description}

\section{LARVA}

- Head

Antennae with scapes and pedicels bare. Frons narrow, sometimes with medial longitudinal keel.

Labrum (Figs. 1, 14, 25) somewhat broader than long, not constricted basally, with small round denticle in anteromedial emargination.

Hypopharynx as in Figure 2.

Left mandible (Figs. 3, 15) with incisors fused at midlength; prostheca single and stout; tuft of setae between prostheca and mola absent. Right mandible (Figs. 4, 16) with incisors basally cleft.

Maxillae (Figs. 5, 17) with two-segmented palps, extending beyond apices of galealaciniae.

Labium (Figs. 6, 18) with three-segmented palps; palp segment 1 longer than segments 2 and 3 combined; segment 2 with well-developed, narrowly rounded distomedial projection; segment 3 conical and fused to segment 2; glossae somewhat broad, narrowly rounded apically, slightly shorter than paraglossae; paraglossae subequal in width to glossae, narrowly rounded apically.

\section{- Thorax}

Legs (Fig. 9, 19) without villopore; anterior and posterior margins of femora almost parallel; tarsal claws (Figs. 10,20) elongate, nearly $0.5 x$ length of tarsus, with minute denticles becoming larger in midregion. Hindwingpads present or absent.

\section{- Abdomen}

Abdomen slightly dorsoventrally flattened.

Terga (Fig. 11) with small ridges throughout surface and posterior triangular spination.

Gills (Figs. 12, 21, 27) on abdominal segments 1-7, plate-like, serrate, held dorsolaterally.

Paraprocts (Fig. 13) with marginal spination increasing in length distally. Three caudal filaments present, with abundant, interlocking setae on the median margins of cerci and lateral margins of median caudal filament, and with whorls of spines on each segment; median caudal filament as long as cerci.

\section{ADULT}

- Head

Male turbinate eyes (Day 1955 : Fig. 22) mounted on relatively short, narrow stalks.

\section{- Thorax}

Male forelegs with tibiae nearly $1.4 \mathrm{x}$ length of femora. Female forelegs with tibiae nearly $1.1 x$ length of femora. Tarsi with ovoid and acute claws. Forewings (Fig. 22) with paired marginal intercalaries. Hindwings absent or, if present, elongate and slender, with two longitudinal veins and compound costal process with two small peaks (Figs. 23, 24).

- Male genitalia (Day 1955 : Fig. 19) with threesegmented forceps; segment 1 broad, nearly $0.6 x$ length of segment 2; segment 2 broad basally, elongate; segment 3 nearly $0.2 x$ length of segment 2 , narrowly ovoid.

\subsection{Diagnosis}

Larvae of Paracloeodes can be readily distinguished by the small body size, distinct shape of the labial palps (Figs. 6, 18), elongate tarsal claws with poorly defined denticulation (Figs. 10, 20), numerous minute ridges on the abdominal terga (Fig. 11), and relatively elongate gills (Figs. 12, 21,27). Adults generally can be distinguished by their small body size and shape of hindwings (Figs. 23, 24), when present.

\subsection{Type species}

Paracloeodes abditus Day $1955[=P$. minutus (Daggy) 1945].

\subsection{Species included}

Paracloeodes binodulus Lugo-Ortiz \& McCafferty, n. sp.; P. eurybranchus Lugo-Ortiz \& McCafferty, n. sp.; P. ibicui Lugo-Ortiz \& McCafferty, n. sp.; P. leptobranchus Lugo-Ortiz \& McCafferty, n. sp.; P. minutus (Daggy); P. lilliputian Kluge; $P$. portoricensis Traver. 


\subsection{Distribution}

Argentina, Brazil, Costa Rica, Cuba, Panama, Paraguay, Puerto Rico, United States.

\subsection{Discussion}

South American Paracloeodes species have characteristics not previously known in the genus. These include the presence of hindwings (three species), small tubercles on the larval mesonotum (one species), and the slightly larger body size (two species).

The presence of hindwings is of particular biogeographic and systematic significance. Because reductionist trends in baetid lineages often include the loss of hindwings (e.g., Acentrella Bengtsson, Baetis Leach, and Cloeodes Traver) (see McCafferty \& Waltz 1990), we interpret the independent loss of hindwings demonstrated in North American and Mesoamerican species to be apomorphic. Furthermore, because species with hindwings (plesiomorphic) are only known from South America, we hypothesize that South America is the center of origin of Paracloeodes.

\section{Paracloeodes binodulus Lugo-Ortiz \& McCafferty, n. sp.}

\subsection{Description}

\section{LARVA}

Body length : $2.7-3.4 \mathrm{~mm}$; caudal filaments length : 1.2-1.8 mm. General coloration yellow-brown.

- Head

Coloration yellow-brown, with no distinct pattern.

Antennae nearly $2.0 x$ length of head capsule.

Labrum (Fig. 1) with scattered long, fine, simple setae dorsally; pair of submedian elongate setae absent; anterior margin with weakly pectinate setae.

Hypopharynx as in Fig. 2.

Left mandible (Fig. 3) with incisors fused at midlength, outer set with four denticles, medial set with two denticles; prostheca stout, appearing with two denticles; small tuft of simple setae at base of triangular process. Right mandible (Fig. 4) with incisors basally cleft, outer set with four denticles, medial set apically acute; prostheca elongate, slender, and pectinate; mola with deep recession at base.

Maxillae (Fig. 5) with two sharp denticles on apex of galealaciniae; palp segments 1 and 2 subequal, covered with fine, simple setae.

Labium (Fig. 6) with numerous long, simple setae apically on glossae and paraglossae; glossae with abundant short, fine, simple setae ventrally; paraglos- sae with submedian row of 8-10 long, fine, simple setae ventrally; segments 2 and 3 of palps with numerous short, fine, simple setae; palp segment 2 without row of setae dorsally.

- Thorax

Coloration yellow-brown, with no distinct pattern.

Two small tubercles present between forewingpads (Figs. 7, 8).

Hindwingpads absent.

Legs (Fig. 9) yellow-brown; femora with eight to nine short, stout setae dorsally; tibiae dorsally bare and with row of five to six setae of medium length ventrally; tarsi dorsally bare and with row of $10-12$ setae of medium length ventrally; tarsal claws (Fig. 10) with 10-12 minute denticles.

\section{- Abdomen}

Coloration yellow-brown, with no distinct pattern.

Terga (Fig. 11) with marginal spines nearly $2.0 x$ basal width.

Gills (Fig. 12) broader on distal half, lacking tracheation.

Paraprocts (Fig. 13) with 14-15 marginal spines, increasing in length distally.

Caudal filaments pale yellow-brown; cerci with six or eight long, simple setae medially on each segment; terminal filament with six or eight long, simple setae laterally on each segment.

\section{ADULT \\ Unknown.}

\subsection{Material examined}

Holotype : Larva, Brazil, Pará State, Rio Tapajóz, Pindobal, VI-20-1946, H. Sioli. Paratype : Larva, Brazil, Pará State, Rio Guamá, Ourém, XI-15-1953, H. Sioli. Additional material : Larva, Brazil, Pará State, Rio Cururú, nr mission, III-31-1941, H. Sioli; two larvae, Brazil, Pará State, Rio Cururú, Cururú Mission, II-4-1961, E. J. Fittkau; two larvae, Brazil, Pará State, Rio Paru, nr Tiriyos Mission, nr BrazilSuriname border, III-13-1953, E. J. Fittkau; larva, Brazil, Pará State, Santarém, Maicá, VI-26-1946, H. Sioli; larva, BRAZIL, Pará State, Paraná do Tapará, VII-15-1946, H. Sioli; two larvae, Brazil, Pará State, Aterno Creek, $21.6 \mathrm{~km}$ from Bragança, XI-14-1953, H. Sioli; nine larvae, same data as holotype; larva, same data as holotype; five larvae, same data as paratype [mouthparts and forelegs of two larvae mounted on slides (medium: Euparal)]; larva, same data as paratype. 

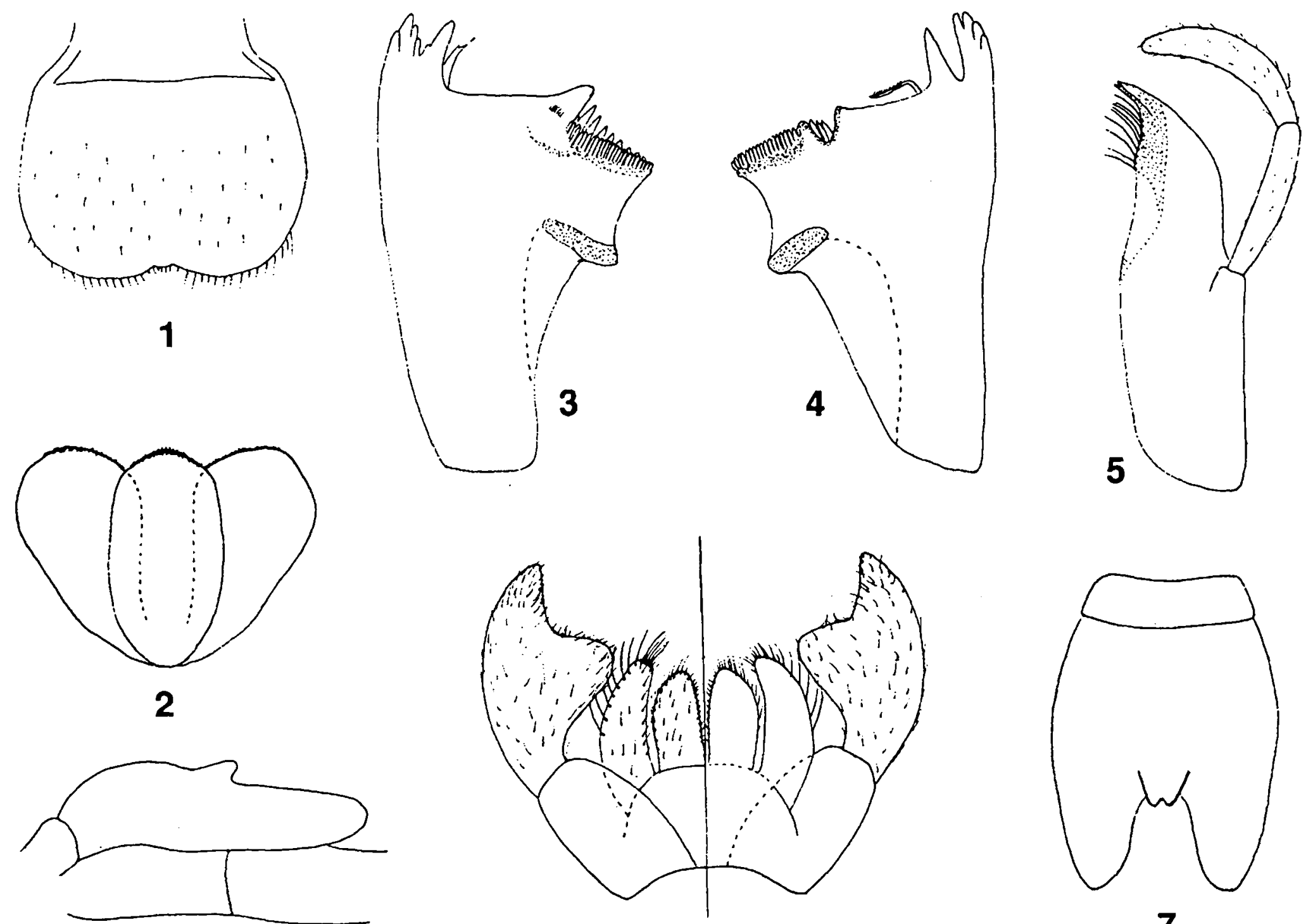

6
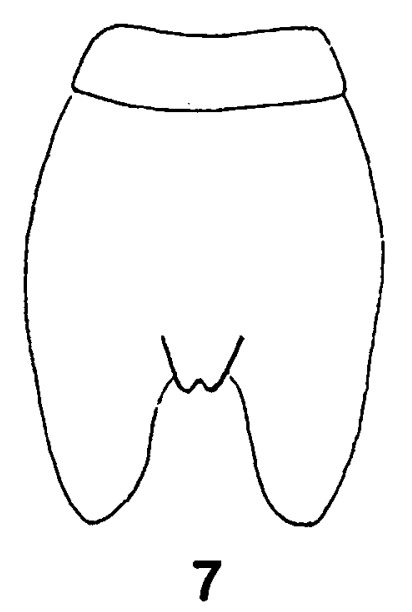

8
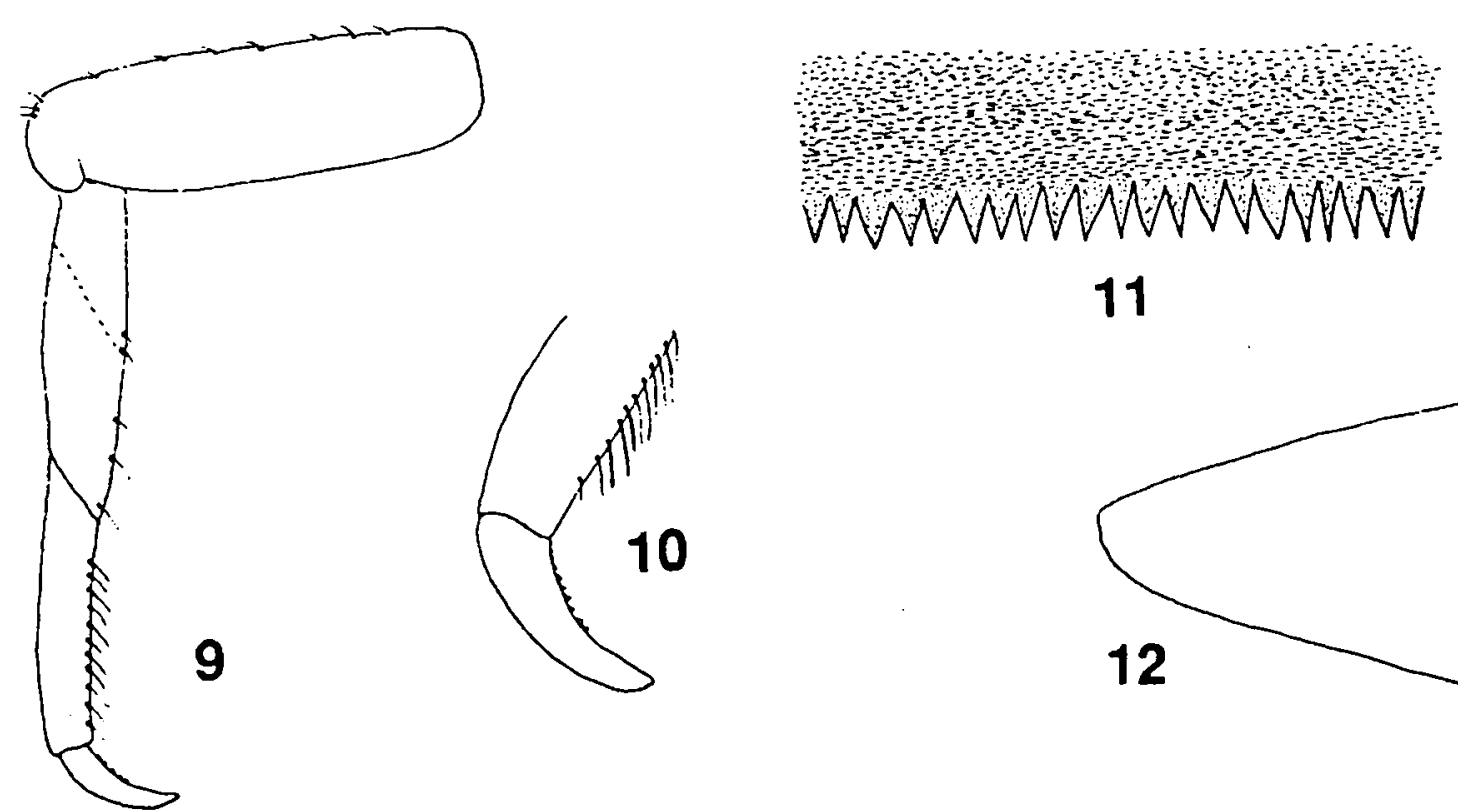

11

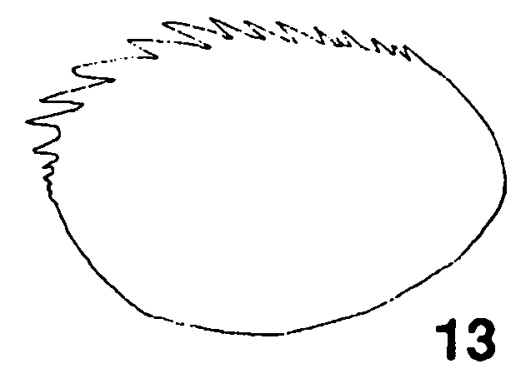

Figs. I to 13. Paracloeodes binodulus, n. sp., larva.

1 : Labrum (dorsal). 2 : Hypopharynx. 3 : Left mandible. 4 : Right mandible. $5:$ Left maxilla. 6 : Labium (left-ventral; right-dorsal). 7 : Mesonotal tubercles (dorsal). $8:$ Mesonotal tubercles (lateral). $9:$ Right foreleg. $10:$ Tarsal claw. $11:$ Tergum $5.12:$ Gill 4 . $13:$ Paraproct.

Fig. 1 à 13. Larve de Paracloeodes binodulus n. sp.

$1:$ Labre en vue dorsale. 2 : Hypopharynx. $3:$ Mandibule gauche. $4:$ Mandibule droite. $5:$ Maxille gauche. $6:$ Labium (vue ventrale à gauche; vue dorsale à droite). 7 : Tubercules mésonotaux en vue dorsale. $8:$ Tubercules mésonotaux en vue latérale. $9:$ Patte antérieure droite. 10: Griffe tarsale. $11:$ Se tergite. $12: 4$ e branchie. $13:$ Paraprocte. 


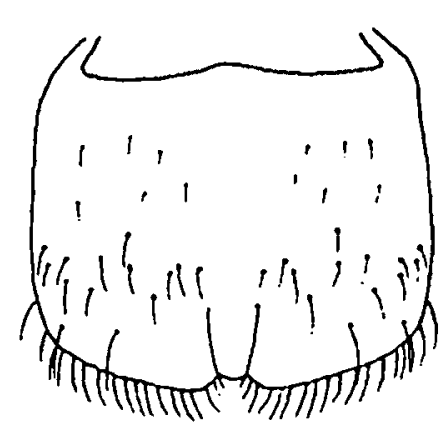

14
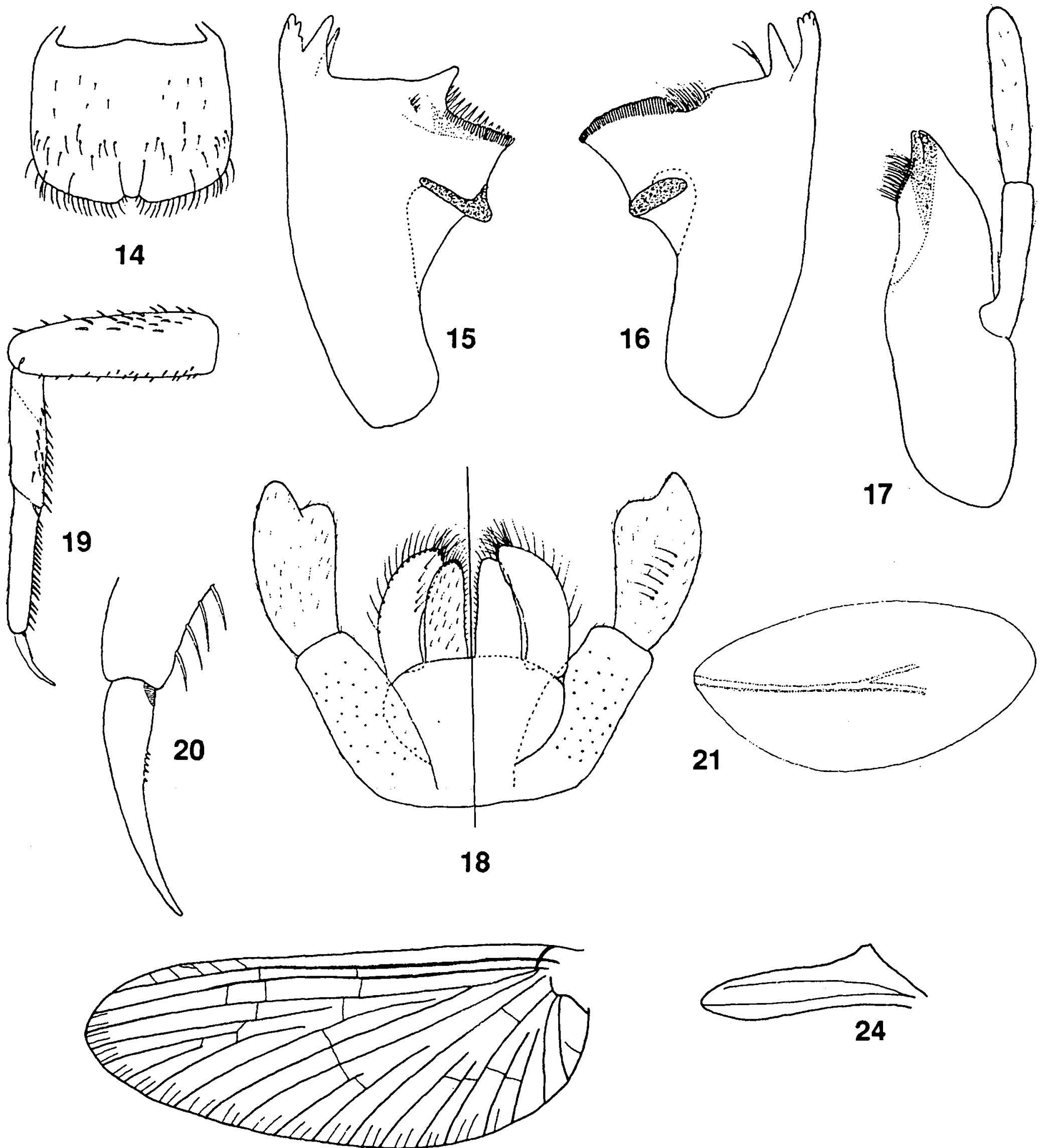

22

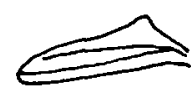

23

Figs. 14 to 24. Paracloeodes eurybranchus, n. sp., larva.

$14:$ Labrum (dorsal). $15:$ Left mandible. 16: Right mandible. $17:$ Left maxilla. $18:$ Labium (left-ventral; right-dorsal). $19:$ Right foreleg. 20 : Tarsal claw. 21 : Gill 4. 22 : Female forewing. 23 : Female hindwing. $24:$ Female hindwing (enlarged).

Fig. 14 à 24. Larve de Paracloeodes eurybranchus n. sp.

$14:$ labre en vue dorsale. $15:$ mandibule gauche. $16:$ mandibule droite. $17:$ maxille gauche. $18:$ labium (vue ventrale à gauche; vue dorsale à droite). $19:$ patte antérieure droite. $20:$ griffe tarsale. $21:$ branchie $4.22:$ aile antérieure femelle. $23:$ aile postérieure femelle. $24:$ aile postérieure femelle (aggrandie). 


\subsection{Etymology}

The specific epithet is an arbitrary combination of letters incorporating the Latin words bi (two) and nodulus (small swelling). It is in reference to the pair of tubercles found between the bases of the forewingpads.

\subsection{Discussion}

Paracloeodes binodulus is readily distinguished by the presence of two small tubercles between the forewingpads (Figs. 7, 8). Also diagnostically, the labrum lacks a pair of long, submedial setae (Fig. 1); the right mandible has a pectinate prostheca that is not bifid, and a deep recession at the base of the mola (Fig. 4); segment 2 of the labial palps has a pronounced distomedial process and lacks a dorsal row of setae (Fig. 6); the tarsal claws are relatively robust (Fig. 10); and the gills are broadest in the distal half (Fig. 12).

\section{Paracloeodes eurybranchus Lugo-Ortiz \& McCafferty, n. sp.}

\subsection{Description}

\section{LARVA}

Body length : 4.7-5.5 mm; caudal filaments length : 1.9-2.2 $\mathrm{mm}$. General coloration yellow-brown.

- Head

Coloration yellow-brown, with no distinct pattern.

Antennae nearly $2.0 x$ length of head capsule.

Labrum (Fig. 14) with scattered long, fine, simple setae dorsally; pair of submedian elongate setae present; anterior margin with weakly pectinate setae.

Hypopharynx similar to Fig. 2.

Left mandible (Fig. 15) with incisors fused at midlength, outer set with four denticles, medial set apically acute; prostheca stout, appearing cleft apically; small tuft of simple setae near base of triangular process. Right mandible (Fig. 16) with incisors basally cleft, outer set with four denticles, medial set apically acute; prostheca bifid; tuft of long, fine, simple setae at base of mola.

Maxillae (Fig. 17) with two small denticles on apex of galealaciniae; palp segments 1 and 2 subequal, covered with short, fine, simple setae.

Labium (Fig. 18) with numerous long, simple setae apically on glossae and paraglossae; glossae with abundant short, fine, simple setae ventrally; paraglossae with submedial row of 8-10 fine, long, simple setae ventrally; segments 2 and 3 of palps with numerous short, fine, simple setae; palp segment 2 with row of five to six long, fine, simple setae dorsally.

\section{- Thorax}

Coloration yellow-brown, with no distinct pattern.

Hindwingpads present.

Legs (Fig. 19) yellow-brown; femora with 9-10 robust, simple setae of medium length dorsally and anteriorly, and scattered short, robust, simple setae ventrally; tibiae with sparse short, fine, simple setae dorsally, scattered fine, simple setae of medium length submarginally, and row of 11-13 setae of increasing length ventrally; tarsi with sparse short, fine, simple setae dorsally and row of 20-21 setae of increasing length ventrally; tarsal claws (Fig. 20) with minute denticles basally and four to six larger denticles in midregion.

\section{- Abdomen}

Coloration yellow-brown, with no distinct pattern.

Terga (similar to Fig. 11) with marginal spines length $2.0 x$ basal width. Gills (Fig. 21) broader in midregion, poorly tracheated.

Paraprocts (similar to Fig. 13) with 14-15 marginal spines, increasing in length distally.

Caudal filaments yellow-brown; cerci with six or eight long, simple setae medially on each segment; terminal filament with six or eight long, simple setae laterally on each segment.

\section{ADULT (FEMALE)}

Body length : 4.3-4.4 mm; forewing length : 4.1-4.2 $\mathrm{mm}$; hindwing length : $0.8-0.9 \mathrm{~mm}$; caudal filaments length : $5.5 \mathrm{~mm}$. General coloration pale yellowbrown.

- Head

Coloration yellow-brown, with no distinct pattern.

Antennae nearly $0.5 x$ length of head width.

- Thorax

Coloration yellow-brown, with no distinct pattern.

Legs cream.

Forewings as in Fig. 22.

Hindwings as in Figs. 23 and 24.

- Abdomen

Abdomen yellow-brown, with no distinct pattern.

Caudal filaments pale cream.

\subsection{Material examined}

Holotype : Larval exuviae, Argentina, Córdoba Province, Río Pocho, ca $25 \mathrm{~km}$ WSW of Sansacate, $1100 \mathrm{~m}$, IV-15/17-1967, L. Peña [exuviae and mouthparts mounted on slides (medium: Euparal)]. Paratypes : three female adults reared from larvae and 
four larval exuviae [fore- and hindwings of one female mounted on slide (medium: alcohol)]; 10 larvae, Argentina, Córdoba Province, ca $25 \mathrm{~km}$ NE of Villa Cura Brochero, IV-14-1967, L. Peña. Additional material : 26 larvae, Argentina, Córdoba Province, ca 25 km NE of Villa Cura Brochero, IV-14-1967, L. Peña; two larvae, Argentina, Córdoba Province, Falda del Carmen, ca $8 \mathrm{~km} \mathrm{~N}$ of Alta Gracia, IV-11-1967, L. Peña; four larvae, Argentina, Córdoba Province, Arroyo Tegua, ca $50 \mathrm{~km} \mathrm{~N}$ of Río Cuarto, IV-5/91967, L. Peña; 173 larvae, Argentina, Córdoba Province, Río Pintos, nr Embalse Cruz del Eje, ca 10 km SE of Cruz del Eje, IV-18/19-1967, L. Peña; four larvae, one female adult, and two female subimagos, same data as holotype; 16 larvae, same data as holotype; 25 larvae, same data as holotype; 12 larvae, Brasil, Rio Grande do Sul State, Arroio Inhandui, $29^{\circ} 52^{\prime} \mathrm{B} / 56^{\circ} 03^{\prime} \mathrm{L}, 120 \mathrm{~m}$, XI-1964, F. Plaumann.

\subsection{Etymology}

The specific epithet is a modified noun in apposition consisting of the Greek words eury (broad) and branchos (gill). It is in reference to the medially broadened gills of this species.

\subsection{Discussion}

Paracloeodes eurybranchus is distinguished in the larval stage by its relatively large size, the presence of hindwingpads, and the medially broadened gills (Fig. 21). The hindwings of female adults (Figs. 23, 24) are most similar to those of some African species currently assigned to Afroptilum Gillies, particularly with respect to the two peaks in the costal process. In general, the hindwings of Paracloeodes (based on P. eurybranchus), as well as the larval mandibles of Paracloeodes, are most typical of Cloeoninae, despite the presence of double marginal intercalaries in the forewings, which are traditionally associated with Baetinae.

\section{Paracloeodes ibicui Lugo-Ortiz \& Mc- Cafferty, n. sp.}

\subsection{Description}

\section{LARVA}

Body length : $3.0 \mathrm{~mm}$; caudal filaments length : 1.5 $\mathrm{mm}$. General coloration medium brown.

- Head

Coloration medium brown, with no distinct pattern.

Antennal length unknown.

Labrum (Fig. 25) with scattered long, fine, simple setae dorsally; pair of submedian elongate setae absent; anterior margin with weakly pectinate setae.
Hypopharynx similar to Fig. 2.

Left mandible (similar to Fig. 3) with incisors fused at midlength, outer set with four denticles, medial set apically acute; prostheca stout, appearing cleft apically; small tuft of simple setae near base of triangular process. Right mandible (similar to Fig. 4) with incisors basally cleft, outer set with four denticles, medial set apically acute; prostheca bifid; tuft of long, simple setae at base of mola.

Maxillae (similar to Fig. 5) with two to four small denticles on apex of galealaciniae; palp segments 1 and 2 subequal, covered with short, fine, simple setae.

Labium (similar to Fig. 6) with numerous long, simple setae apically on glossae and paraglossae; glossae with abundant short, fine, simple setae ventrally; paraglossae with submedial row of 8-10 long, fine, simple setae ventrally; segments 2 and 3 of palps with numerous short, fine, simple setae; palp segment 2 with row of five to six long, fine, simple setae dorsally.

\section{- Thorax}

Coloration medium brown, with no distinct pattern.

Hindwingpads present.

Legs (similar to Fig. 19) medium brown; femora with medium brown medial marking on anterior face and with 9-10 robust, simple setae of medium length dorsally and anteriorly, and scattered short, robust, simple setae ventrally; tibiae with sparse short, fine, simple setae dorsally, scattered fine, simple setae of medium length submarginally, and row of 11-13 setae of increasing length ventrally; tarsi with sparse short, fine, simple setae dorsally and row of 20-21 setae of increasing length ventrally; tarsal claws (similar to Fig. 20) with minute denticles basally and four to six larger denticles in midregion.

\section{- Abdomen}

Coloration medium brown, with dark brown longitudinal median streak on terga 1-9; tergum 10 with thin dark brown streak (Fig. 26).

Terga (similar to Fig. 11) with marginal spines length $2.0 \mathrm{x}$ basal width. Gills (similar to Figs. 27, 28) elongate and slender, weakly tracheated. Paraprocts (similar to Fig. 13) with 14-15 marginal spines, increasing in length distally.

\section{ADULT \\ Unknown.}

\subsection{Material examined}

Holotype : Larva, Paraguay, Paraguarí Department, Parque Nacional Ybicuí, Arroyo Mina, edge, IV-20- 
1984, R. T. Bonace [mouthparts on slide (medium: Euparal)].

\subsection{Etymology}

The specific epithet is the latinized form of the Ybycuí, or the Ybycuí National Park, where the holotype was collected. It is a noun in apposition.

\subsection{Discussion}

The description of $P$. ibicui is based on a male lastinstar larva. Other species of Paracloeodes were collected from the same locality, but P. ibicui is clearly distinguished by the labral setation (Fig. 25) and presence of a mediodorsal longitudinal abdominal streak (Fig. 26).

\section{Paracloeodes leptobranchus Lugo-Ortiz \& McCafferty, n. sp.}

\subsection{Description}

\section{LARVA}

Body length : $3.9-4.1 \mathrm{~mm}$; caudal filaments length : unknown. General coloration yellow-brown.

- Head

Coloration yellow-brown, with no distinct pattern.

Antennae nearly $2.5 x$ length of head capsule.

Labrum (similar to Fig. 14) with scattered long, fine, simple setae dorsally; pair of submedian elongate setae present; anterior margin with weakly pectinate setae:

Hypopharynx similar to Fig. 2.

Left mandible (similar to Fig. 15) with incisors fused at midlength, outer set with four denticles, medial set apically acute; prostheca stout, appearing cleft apically; small tuft of short, simple setae near base of triangular process. Right mandible (similar to Fig. 16) with incisors basally cleft, outer set with four denticlés; medial set apically acute; prostheca bifid; tuft of long, simple setae at base of mola.

Maxillae (similar to Fig. 17) with two small denticles on apex of galealaciniae; palp segments 1 and 2 subequal, covered with fine, small, simple setae.

Labium (similar to Fig. 18) with numerous long, simple setae apically on glossae and paraglossae; glossae with abundant short, fine, simple setae ventrally; paraglossae with submedial row of 8-10 long, fine, simple setae ventrally; segments 2 and 3 of palps with numerous short, fine, simple setae; palp segment 2 with row of five to six long, fine, simple setae dorsally.

- Thorax

Coloration yellow-brown, with no distinct pattern.

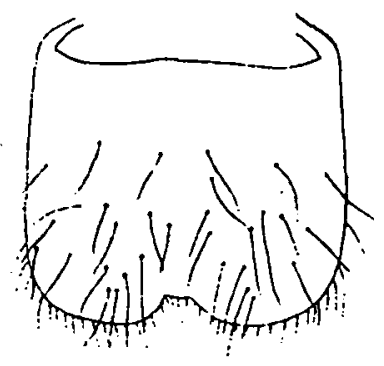

25

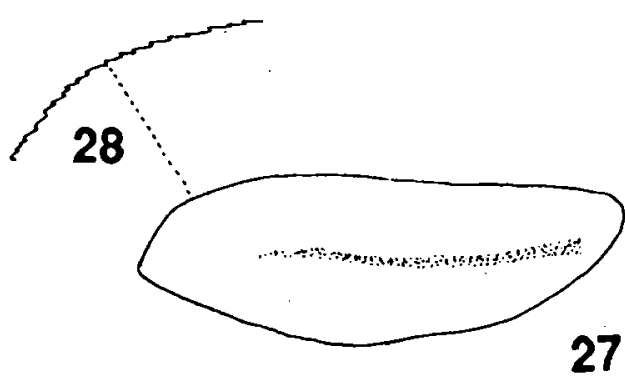

27

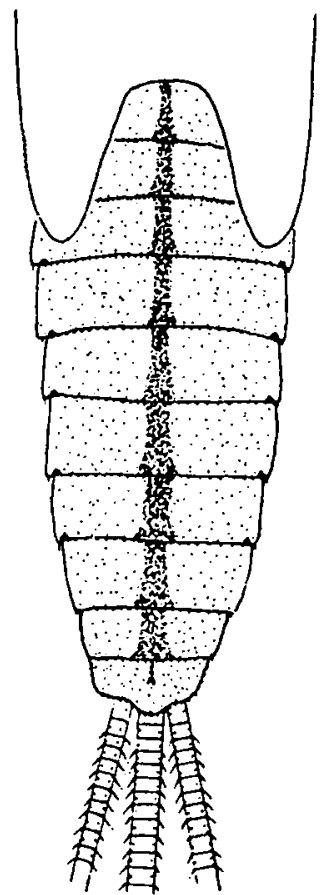

26
Figs. 25 to 28. Paracloeodes ssp. 25 to 26 : Paracloeodes ibicui, n.sp., larva. 25 : Labrum (dorsal). 26 : Abdomen (dorsal)

27 to 28. Paracloeodes leptobranchus, n.sp., larva. 27 : Gill 4. 28 : Gill margin.

Fig. 25 à 28. Paracloeodes ssp. 25-26: larve de Paracloeodes ibicui, n.sp., 25 : labre (vue dorsale). $26:$ Abdomen (vue dorsale). 27-28: larve de Paracloeodes leptobranchus n.sp. 27 : branchie 4. 28 : Bord de la branchie.

\section{Hindwingpads present.}

Legs (as in Fig. 19) yellow-brown; femora with medium brown medial marking on anterior face and with $9-10$ robust, simple setae of medium length dorsally and anteriorly, and scattered short, robust, simple setae ventrally; tibiae with sparse short, fine, simple setae dorsally, scattered fine, simple setae of medium length submarginally, and row of 11-13 setae of increasing length ventrally; tarsi with sparse short, fine, simple setae dorsally and row of 20-21 setae of increasing length ventrally; tarsal claws (similar to Fig. 20) with minute denticles basally and four to six larger denticles in midregion.

\section{- Abdomen}

Coloration yellow-brown to medium brown, sometimes with two faint submedial, longitudinal bands on terga 3-7.

Terga (similar to Fig. 11) with marginal spines length $2.0 x$ basal width. Gills (Figs. 27, 28) elongate and slender, weakly tracheated. 
Paraprocts (as in Fig. 13) with 14-15 marginal spines, increasing in length distally.

\section{ADULT}

Unknown.

\subsection{Material examined}

Holotype : Larva, Brazil, Rio Grande do Sul State, Campos Novas, Rio Leão, $800 \mathrm{~m}, 27^{\circ} 19^{\prime} \mathrm{B} / 51^{\circ} 18^{\prime} \mathrm{L}$, V-1962, F. Plaumann [mouthparts, right foreleg, and gill 4 mounted on slide (medium: Euparal)]. Paratypes : Larva, Brazil, Santa Catarina State, Aparados da Serra, Rio Quatis, $1900 \mathrm{~m}$, $28^{\circ} 42^{\prime} \mathrm{S} / 50^{\circ} 27^{\prime} \mathrm{W}$, IV-1967, F. Plaumann; larva, Brazil, Paraná State, Guarapuava, Rio das Mortes, $1100 \mathrm{~m}, 25^{\circ} 20^{\prime} \mathrm{B} / 51^{\circ} 27^{\prime} \mathrm{L}$, III-1963, F. Plaumann; larva, Brazil, Paraná State, Rio Irany, $600 \mathrm{~m}$, $26^{\circ} 55^{\prime} \mathrm{B} / 51^{\circ} 47^{\prime} \mathrm{L}$, IV-1962, F. Plaumann; larva, Paraguay, Paraguarí Department, Parque Nacional Ybycuí, Laguna de «La Rosada,» VIII-3-1984, R. T. Bonace. Additional material : Two larvae, Brazil, Rio Grande do Sul State, Lavras do Sul, $280 \mathrm{~m}$, $30^{\circ} 48^{\prime} \mathrm{B} / 53^{\circ} 55^{\prime} \mathrm{L}$, XI-1964, F. Plaumann; four larvae, Brazil, Rio Grande do Sul State, Lavras do Sul, $30^{\circ} 48^{\prime} \mathrm{B} / 53^{\circ} 55^{\prime} \mathrm{L}, 280 \mathrm{~m}$, XI-1964, F. Plaumann; larva, Brazil, Santa Catarina State, Irany, XI-1962, F. Plaumann; larva, Paraguay, Amambay Department, Parque Nacional Cora, Arroyo Panambay, pool, XI-51983, R. T. Bonace; two larvae, Paraguay, Cordillera Department, Piribebuy, Río Piribebuy, V-3-1985, R. T. Bonace; larva; Paraguay, Paraguarí Department, Parque Nacional Ybycuí, Laguna de «La Rosada,» VIII-3-1984, R. T. Bonace; larva, Paraguay, Paraguarí Department, Parque Nacional Ybycuí, tributary of Arroyo Corrientes, I-26-1985, R. T. Bonace; 11 larvae, PARAGUAY, Paraguarí Department, Parque Nacional Ybycuí, Arroyo Mina, pool, VIII-2-1984, R. T. Bonace; two larvae, Paraguay, Paraguarí Department, Parque Nacional Ybycuí, Arroyo Mina, pool, VIII-21984, R. T. Bonace; nine larvae, Paraguay Y, Paraguarí Department, Parque Nacional Ybycuí, Arroyo Mina, edge, X-2-1984, R. T. Bonace; same data except IV20-1984; same data, except four larvae, VII-18-1985; five larvae, Paraguay, Paraguarí Department, Parque Nacional Ybycuí, Arroyo Mina, edge, IX-2-1984, R. T. Bonace; same data except three larvae, VII-181985; two larvae, Paraguay, Paraguarí Department,
Cerro Acahay, Arroyo, V-31-1985, R. T. Bonace; larva, Paraguay, Paraguarí Department, Arroyo Apichapa, km A 135, Ruta 1, VIII-9-1984, R. T. Bonace.

\subsection{Etymology}

The specific epithet is a modified noun in apposition from the Greek words leptos (slender) and branchos (gill). It is an allusion to the slender gills of the larvae.

\subsection{Discussion}

Paracloeodes leptobranchos is similar to $P$. eurybranchus and $P$. ibicui. It differs from $P$. eurybranchus in being smaller and in possessing slender gills that are marginally serrate (Figs. 27, 28). It differs from $P$. ibicui in lacking a dorsal abdominal streak.

\section{Acknowledgments}

We thank G. F. Edmunds, Jr. (Salt Lake City, Utah) for the donation of the material used in this study. We also thank A. Thomas (Toulouse, France) for his assistance in the preparation of the manuscript. This paper has been assigned Purdue Agricultural Research Program Journal No. 15012

\section{References}

Daggy R. H. 1945. - New species and previously undescribed naiads of some Minnesota mayflies (Ephemeroptera). Ann. entomol. Soc. Am., 38 : 373-396.

Day W. C. 1955. - New genera of mayflies from California. PanPac. Entomol., $31: 121-137$.

Flowers R. W. 1991. - Diversity of stream-living insects in northwestern Panamá. J. N. Am. Benthol. Soc., 10 : 322-334.

Kluge N. Y. 1991. - Cuban mayflies of the family Baetidae (Ephemeroptera) 1. Genera Callibaetis, Cloeodes and Paracloeodes. Zool. Zh., 12 : 128-135. [In Russian.]

Lugo-Ortiz C. R., W. P. McCafferty \& R. D. Waltz. 1994. Contribution to the taxonomy of the Panamerican genus Fallceon (Ephemeroptera: Baetidae). J. New York entomol. Soc., 102 : 460475.

McCafferty W. P \& C. R. Lugo-Ortiz. 1996. - Los efemerópteros (Ephemeroptera) de América Central. Rev. Nica. Entomol., 35 : 19-28.

McCafferty W. P. \& R. D. Waltz. 1990. - Revisionary synopsis of the Baetidae (Ephemeroptera) of North and Middle America. Trans. Am. entomol. Soc., $116: 769-799$.

McCafferty W. P., R. W. Flowers \& R. D. Waltz. 1992. - The biogeography of Mesoamerican mayflies, pp. 173-193. In : S. P. Darwin and A. L. Welden (eds.), Biogeography of Mesoamerica: proceedings of a symposium. Tulane Univ. Stud. Zool. Bot., Suppl. Publ. 1.

Traver J. R. 1938. - Mayflies of Puerto Rico. J. Ag. Univ. Puerto Rico, $22: 5-42$ 